\title{
Citral reduces nociceptive and inflammatory response in rodents
}

\author{
Lucindo J. Quintans-Júnior, ${ }^{* 1}$ Adriana G. Guimarães, ${ }^{1}$ Marilia T. \\ de Santana, ${ }^{1}$ Bruno E.S. Araújo, ${ }^{1}$ Flávia V. Moreira, ${ }^{1}$ Leonardo $R$. \\ Bonjardim, ${ }^{1}$ Adriano A. S. Araújo, ${ }^{1}$ Jullyana S. Siqueira, ${ }^{1}$ Ângelo \\ R. Antoniolli, ${ }^{1}$ Marco A. Botelho, ${ }^{2}$ Jackson R. G. S. Almeida, ${ }^{3}$ \\ Márcio R. V. Santos ${ }^{1}$
}

${ }^{1}$ Departamento de Fisiologia, Universidade Federal de Sergipe, Brazil,

${ }^{2}$ Laboratório de Biotecnologia, Instituto Federal de Educação Ciência e Tecnologia do Ceará, Brazil,

${ }^{3}$ Núcleo de Estudos e Pesquisas de Plantas Medicinais, Universidade Federal do Vale do São Francisco, Brazil.
Revista Brasileira de Farmacognosia Brazilian Journal of Pharmacognosy 21(3): 497-502, May./Jun. 2011

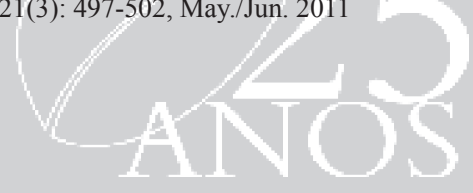

\section{Article}

Received 21 Aug 2010 Accepted 25 Oct 2010 Available online 20 Apr 2011

Keywords: monoterpene citral antinociceptive anti-inflammatory

ISSN 0102-695X doi: $10.1590 / \mathrm{S} 0102-695 \mathrm{X} 2011005000065$

\section{Introduction}

Treatments of some painful conditions, such as inflammatory and neurogenic pain, are often unsatisfactory because its etiology is heterogeneous and the underlying pathophysiology mechanisms are complex (Batista et al., 2010). Moreover, currently available drugs that provide relief from these painful conditions are effective only in a fraction of patients. In general, these drugs present low efficacy and numerous side effects (Basbaum, 1999; Mendell \& Sahenk, 2003). In this context, natural products that present fewer side effects emerge as interesting therapeutic resources for the development of new drugs for the management of certain painful states (McCurdy \& Scully, 2005; Batista et al., 2010).

An increasing number of studies have demonstrated that essential oils derived plant exhibit a variety of biological properties, such as analgesic (McCurdy \& Scully, 2005), hypotensive (Menezes et al., 2010) and anticonvulsant activities (QuintansJúnior et al., 2008a; Silva et al., 2010). Monoterpenes are the primary components of these essential oils and the effects of many medicinal herbs have been attributed to them (Lima-Accioly et al., 2006; Quintans-Júnior et al., 2008b), including the studies realized by our group (De Sousa et al., 2006; 2007; Melo et al., 2010; Quintans-Júnior et al., 2010; Guimarães et al., 2010).

In this regard, preliminary pharmacological screening realized with the essential oil of the Cymbopogon winterianus (rich in citronellal, citronellol and citral) demonstrates CNS depressant, anticonvulsant, hypotensive, vasorelaxat and antinociceptive activities in rodents (Quintans-Júnior et al., 2008a; Menezes et al., 2010; Leite et al., 2010). Gurgel do Vale et al. (2002) demonstrates that Lippia alba essential oil (rich in citral 
and myrcene) possess anxiolytic and depressant effects in experimental animals. In same study, authors showed that isolated compound (citral) possess CNS depressant activity in rodents. However, little is known about the possible antinociceptive and anti-inflammatory activities of citral (CIT).

Thus, the purpose of the present study was to evaluate both antinociceptive and anti-inflammatory activities of CIT in rodents.

\section{Material and Methods}

\section{Chemicals}

Acetic acid, carrageenan, diazepam, citral (minimum 95\%, mixture of cis (1a) and trans (1b) isomers, 3,7-dimethyl-2,6-octadienal (1)), and polyoxyethylenesorbitan monolate (Tween 80) were purchased from Sigma (USA). Morphine (MOR) and Indomethacin (INDO), were purchased from União Química Farmacêutica Nacional (Brazil). The citral (CIT) was administered intraperitoneally (i.p.) in volumes of $0.1 \mathrm{~mL} / 10 \mathrm{~g}$ and the doses $(50,100$ or $200 \mathrm{mg} / \mathrm{kg})$ were adjusted for those respective volumes.

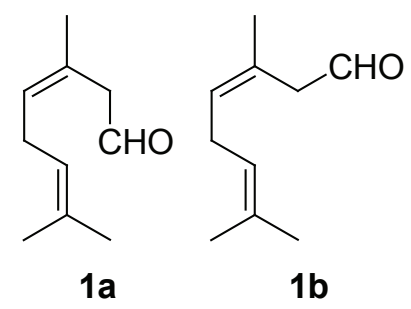

Animals

Male Swiss mice (31-36 g) and male Wistar rats (150-170 g), 2-3 months of age, were used throughout this study. The animals were randomly housed in appropriate cages at $21 \pm 2{ }^{\circ} \mathrm{C}$ on a $12 \mathrm{~h}$ light/dark cycle (lights on 6:0018:00 h) with free access to food and water. Experiments were carried out between 9:00 am and 14:00 pm in a quiet room. Nociceptive and inflammatory tests were carried out by the same visual observer and all efforts were made to minimize the number of animals used as well as any discomfort. Experimental protocols were approved by the Animal Care and Use Committee (CEPA/UFS \# 26/09) at the Federal University of Sergipe and handling procedures were in accordance with International Association for the Study of Pain guidelines for the use of animals in pain research (Zimmermann, 1983).

Antinociceptive activity

Acetic acid-induced writhing
The acetic acid test was done using the method described by Koster et al. (1959) and modified by Gaertner et al. (1999). Initially, the mice were divided into five groups ( $\mathrm{n}=8$, per group). Subsequently, CIT (50, 100 or $200 \mathrm{mg} / \mathrm{kg}$ ), vehicle (saline+Tween $800.2 \%$ ), and MOR $(5 \mathrm{mg} / \mathrm{kg}$ ) were administered i.p. $30 \mathrm{~min}$ before an injection of $0.25 \mathrm{~mL}$ per animal of the acetic acid $(0.8 \%)$. Each animal was isolated in an individual observation chamber and $5 \mathrm{~min}$ after acetic acid injection the cumulative number of writhing responses was recorded for $15 \mathrm{~min}$.

\section{Formalin induced nociception}

The observation chamber was a glass box of 30 $\mathrm{cm}$ diameter on an acrylic transparent plate floor. Beneath the floor, a mirror was mounted at a $45^{\circ}$ angle to allow clear observation of the paws of the mice. The animals were treated with the vehicle (saline+Tween $800.2 \%$ ), CIT $(50,100$, and $200 \mathrm{mg} / \mathrm{kg}$, i.p.), or the reference drug (MOR, $5 \mathrm{mg} / \mathrm{kg}$, i.p.) $30 \mathrm{~min}$ before the formalin injection. Each mouse was placed in the chamber more than $5 \mathrm{~min}$ before treatment in order to allow acclimatization to the new environment. The formalin test was carried out as described by Hunskaar \& Hole (1987). Twenty microliters of a $1.0 \%$ formalin solution $(0.92 \%$ formaldehyde) in a phosphate-buffer ( $\mathrm{pH}$ 7.2) were injected into the dorsal surface of the left hind paw using a microsyringe with a 26-gauge needle. Each animal was then returned to the chamber and the amount of time that the animal spent licking the injected paw was considered to be indicative of pain. Two distinct phases of intensive licking activity were identified: an early acute phase and a late or tonic phase (0-5 and 15-30 min after formalin injection, respectively) (Le Bars et al., 2001).

\section{Anti-inflammatory activity}

\section{Leukocyte migration to the peritoneal cavity}

The leukocyte migration was induced by injection

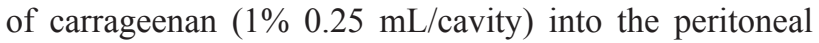
cavity of mice $30 \mathrm{~min}$ after administration of CIT (50, 100, and $200 \mathrm{mg} / \mathrm{kg}$, i.p.) or dexamethasone ( $2 \mathrm{mg} / \mathrm{kg}$, s.c., $\mathrm{n}=6$ per group) by modification of the technique previously described by Bastos et al. (2007). The mice were euthanized by cervical dislocation $4 \mathrm{~h}$ after carrageenan injection. Shortly after, phosphate buffered saline (PBS) containing EDTA (1 mM, i.p., $10 \mathrm{~mL})$ was injected. Immediately a brief massage was done for further fluid collection, which was centrifuged (2000 rpm, $5 \mathrm{~min}$ ) at room temperature. The supernatant was disposed and $1 \mathrm{~mL}$ of PBS was introduced to the precipitate. An aliquot of $10 \mu \mathrm{L}$ from this suspension was dissolved in $200 \mu \mathrm{L}$ of Turk solution and the total cells were counted in a Neubauer chamber, 
under optic microscopy. The results were expressed as the number of leukocytes $/ \mathrm{mL}$. The percentage of the leukocyte inhibition $=(1-T / C) \times 100$, where $\mathrm{T}$ represents the treated groups leukocyte counts and $\mathrm{C}$ represents the control group leukocyte counts.

\section{Carrageenan-induced paw edema test}

Acute hind paw edema was produced by injecting $0.1 \mathrm{~mL}$ of carrageenan $(1 \%$, prepared as a suspension in distillate water plus Tween- 80 at $0.2 \%$ ) locally into the subplantar aponeurosis of the right hind paw of rats (Winter et al., 1962). Animals were divided into five groups ( $\mathrm{n}=6$, per group). CIT (50, 100 or $200 \mathrm{mg} / \mathrm{kg}$, i.p.), vehicle (saline+Tween $800.2 \%$ ) or the standard drug indomethacin (INDO, $10 \mathrm{mg} / \mathrm{kg}$, p.o.) was administered before the carrageenan-induced paw edema. CIT and INDO were administered $1 \mathrm{~h}$ prior to injection of carrageenan (Amresh et al., 2007). Right paw volume was measured by the dislocation of the water column of a plethysmograph (EFF-304, Insight ${ }^{\circledR}$, Brazil) immediately after carrageenin application (time zero) and at 1, 2, 3, and $4 \mathrm{~h}$ after its administration.

\section{Statistical analysis}

The data obtained were evaluated by one-way analysis of variance (ANOVA) followed by Tukey's test for antinociceptive and anti-inflammatory activities. In all cases differences were considered significant if $p<0.05$. The percentile of inhibition of edema volume between treated and control group (vehicle) was calculated using the following formula: Inhibition $\%=100 \times\left(\mathrm{V}_{c}-\mathrm{V}_{\mathrm{t}}\right) / \mathrm{V}_{\mathrm{c}}$. Where $\mathrm{V}_{\mathrm{c}}$ and $\mathrm{V}_{\mathrm{t}}$ represent mean increase in paw volume in control and treated groups, respectively.

\section{Results and Discussion}

Initially, antinociceptive activity of CIT was evaluated by using the writhing test. Intraperitoneal (i.p.) administration of CIT, in all doses, $30 \mathrm{~min}$. before the acid injection, produced a significant $(p<0.001)$ inhibition of acetic acid-induced abdominal constrictions in mice (Figure 1). MOR (5 mg/kg), a standard drug, used as positive control, also produced significant inhibition of acetic acid-induced writhing response.

Acetic acid-induced abdominal constriction is a standard, simple, and sensitive test for measuring analgesia induced by both opioids and peripherally acting analgesics (Hunskaar \& Hole, 1987). In acetic acid-induced abdominal writhing, pain is elicited by the injection of an irritant such as acetic acid into the peritoneal cavity which produces episodes of characteristic stretching (writhing) movements, and inhibition of the number of episodes by analgesics is easily quantifiable. Moreover, it is already well documented that the quantification of prostaglandins by radioimmunoassay in the peritoneal exudates of rodents obtained after the i.p. administration of acetic acid demonstrated high levels of prostaglandins $\mathrm{PGE}_{2}$ and $\mathrm{PGF}_{2 \alpha}$ during $0.5 \mathrm{~h}$ after stimulus (Deraedt et al., 1980). These results support the hypothesis of CIT participation in the inhibition of prostaglandin synthesis; the nociceptive mechanism involves the process or release of arachidonic acid metabolites via cyclooxygenase (COX) and prostaglandin biosynthesis (Duarte et al., 1988) during abdominal writhing induced by acetic acid. Although, this method presents a good sensitivity, it shows poor specificity (Le Bars et al., 2001).

Thus, to avoid misinterpretation of the results, in the present study we confirmed the antinociceptive effect of CIT in a model of inflammatory nociception, the formalin test, which has two distinctive phases that can possibly indicate different types of nociception (Hunskaar \& Hole, 1987). CIT produces antinociceptive effects on both first (0-5 $\mathrm{min})$ and second phases (15-30 $\mathrm{min})$ of formalin induced nociception. The early phase, named neurogenic nociception, is a result of direct stimulation of nociceptors and reflects centrally mediated nociception; the late phase, named inflammatory nociception, is caused by local inflammation with a release of inflammatory and hyperalgesic mediators (Hunskaar \& Hole, 1987). First phase was blocked only at $200 \mathrm{mg} / \mathrm{kg}(p<0.001)$ whereas the higher doses of CIT (100 and $200 \mathrm{mg} / \mathrm{kg}$ ) significantly $(p<0.001)$ blocked the inflammatory nociception. CIT was found to inhibit the inflammation induced nociception better than the neurogenic nociception. MOR $(5 \mathrm{mg} / \mathrm{kg})$ was significantly active $(p<0.001)$ in the both phases of in formalin test (Figure 2).

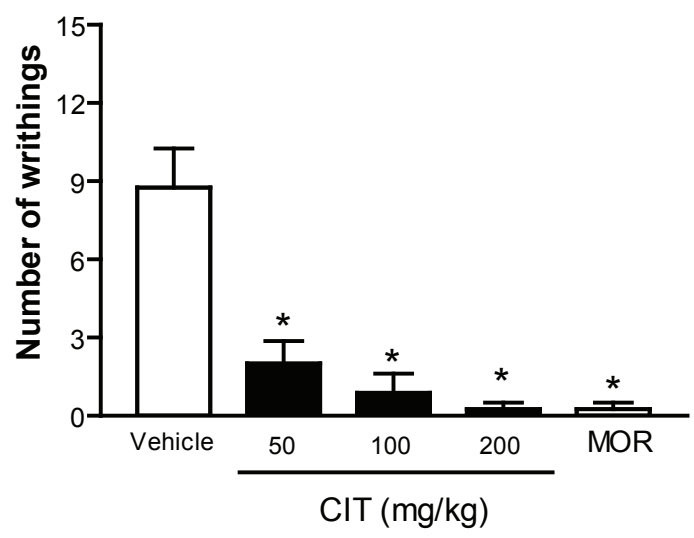

Figure 1. Effects of CIT or MOR on the acetic acid-induced writhing test in the absence and presence of naloxone in mice. Vehicle (control), CIT $(50,100$ or $200 \mathrm{mg} / \mathrm{kg}$ ) or morphine (MOR) were administered i.p. $0.5 \mathrm{~h}$ before acetic acid injection. Each column represents mean \pm SEM. $\mathrm{n}=8 ; *_{p}<0.001$ vs control (ANOVA followed by Tukey's test). 
A)

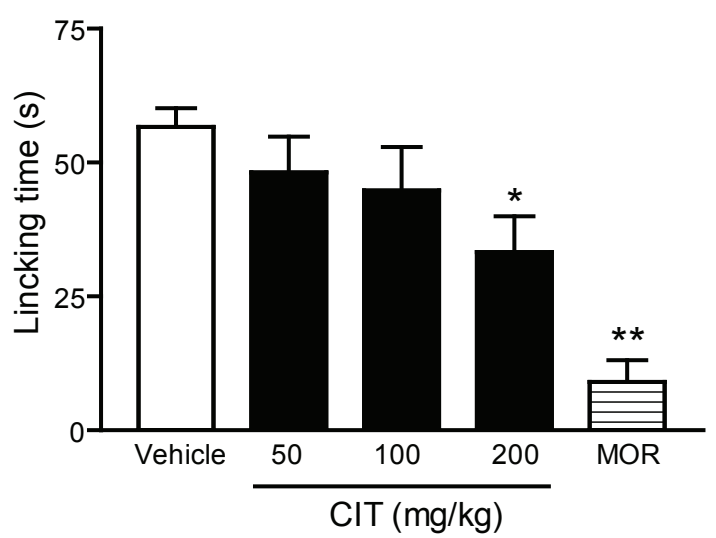

B)

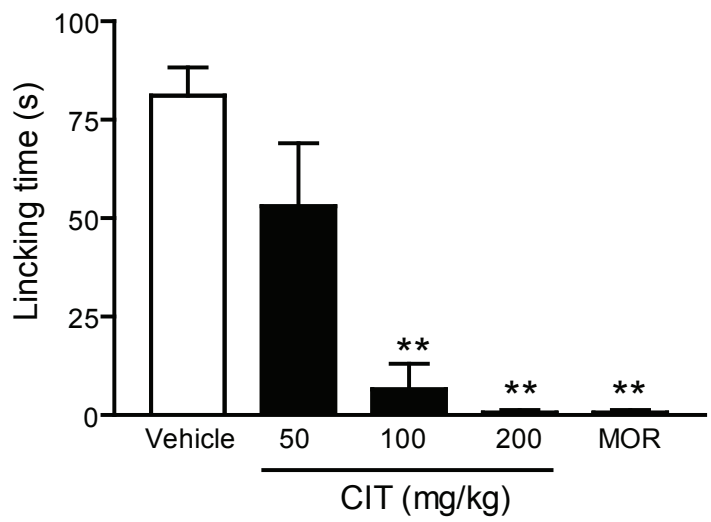

Figure 2. Effects of CIT on the formalin-induced nociception in mice. Vehicle (control), CIT (50, 100 and $200 \mathrm{mg} / \mathrm{kg}$ ) or morphine (MOR) were administered i.p. $0.5 \mathrm{~h}$ before formalin injection. A. Represents the first phase and B. represents second phase of formalin-induced nociception. Each column represents mean \pm SEM. $\mathrm{n}=8 ;{ }^{*} p<0.05$ or ${ }^{* *} p<0.001$ vs control (ANOVA followed by Tukey's test).

In this regards, Waning et al. (2007) demonstrated that the capsaicin-sensitive transient receptor potential vaniloid 1 (TRPV1), which plays an important role in pain transduction, is one of the $\mathrm{Ca}^{+2}$ influx channels involved in cell migration. It was also shown that TRPV1 activation increases the expression of the TNF receptor 1 (TNFR1) by a ROS-dependent mechanism (Ma et al., 2009). According to Stotz et al. (2008) partial TRPV1 agonists, such as CIT, might be useful in anti-inflammatory and analgesic compounds.

Since in previous nociception tests, CIT showed better action in inflammatory pain, we verified the effects of CIT in tests of acute inflammation. Initially, we performed the carrageenan-induced leukocytes migration to the peritoneal cavity. Figure 3 shows the inhibitory effect of CIT (higher doses) on leukocytes migration after $4 \mathrm{~h}$ of the stimulus $(p<0.001)$. Standard drug, dexamethasone (Dexa, $2 \mathrm{mg} / \mathrm{kg}$, s.c.) significantly inhibited $(p<0.001)$ the carrageenan-induced leukocytes migration to the peritoneal cavity.

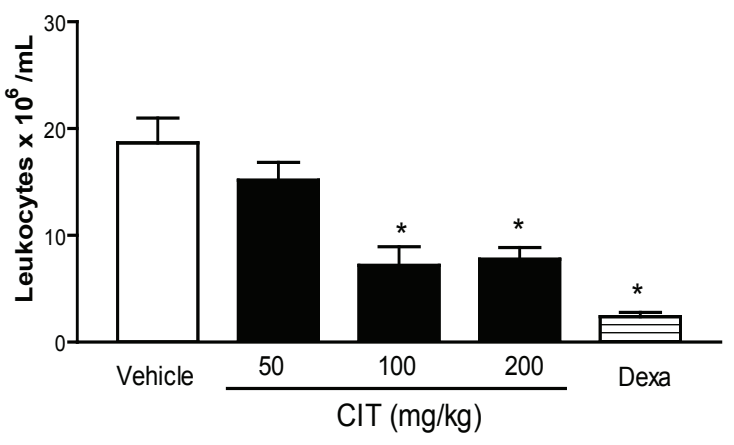

Figure 3. Effect of CIT on leukocyte migration into the peritoneal cavity induced by carrageenan in mice. Groups of mice were pre-treated with vehicle (control), CIT $(50,100$ or $200 \mathrm{mg} / \mathrm{kg}$, i.p.) or dexamethasone (Dexa, $2 \mathrm{mg} / \mathrm{kg}$, s.c.) $0.5 \mathrm{~h}$ before carrageenan $(1 \% 0.25 \mathrm{~mL} /$ cavity i.p. $)$ induced peritonitis. Cell counts were performed at the time $4 \mathrm{~h}$ after the injection of carrageenan. Each value represents the mean \pm SEM. Asterisks denote statistical significance, $* p<0.001$ related to control group. ANOVA followed by Tukey's test ( $\mathrm{n}=6$, per group).

Cell recruitment during inflammation depends on the orchestrated release of local mediators that are responsible for local vascular and tissue changes as well as for the recruitment of host defense cells (Luster et al., 2005). The inflammation induced by carrageenan involves cell migration, plasma exsudation and production of mediators, such as nitric oxide, prostaglandin E2, interleukin (IL)-1 $\beta$, IL-6 and tumor necrosis factor (TNF)- $\alpha$ (Salvemini et al., 1996; Loram et al., 2007). Those mediators are able to recruit leukocytes, such as neutrophils, in several experimental models. CIT inhibited leukocyte migration induced by i.p. injection of carrageenan (in peritonitis model) in higher doses. A putative mechanism associated with this activity may be inhibition of the synthesis of many inflammatory mediators whose involvement in the cell migration is well established. In this regards, Katsukawa et al. (2010) identified CIT as a suppressor of COX-2 and an activator of peroxisome proliferator-activated receptors (PPAR) $\alpha$ and $\gamma$. Moreover, Lee et al. (2008) showed that CIT inhibits NO generation through suppression of iNOS expression via inhibition of NF- $\mathrm{KB}$ activation.

Besides, an additionally test was performed to verify the effects of CIT in the inflammation, by using carrageenan-induced paw edema test. The initial phase of carrageenan paw edema is mediated by histamine and serotonin, while the mediators in the later phase were suggested to be arachidonate metabolites (prostaglandins and leukotrienes) producing an edema dependent on the mobilization of neutrophils (Vinegar et al., 1987; Hwang et al.; 1996). Moreover, it should be taken into consideration that the mechanism involved in the genesis of the carrageenan-induced edema can cause the release of prostaglandins and kinins, among other substances (Garcia- 
Table 1. Effect of citral (CIT) or indomethacin (INDO) on carrageenan-induced paw edema in rats.

\begin{tabular}{lcccccc}
\hline \multirow{2}{*}{ Treatment } & Dose $(\mathrm{mg} / \mathrm{kg})$ & \multicolumn{3}{c}{ Right hind paw edema $(\mathrm{ml})^{\mathrm{a}}$} & \multirow{2}{*}{ \% Edema Inhibition } \\
\cline { 3 - 6 } & & $1 \mathrm{~h}$ & $2 \mathrm{~h}$ & $3 \mathrm{~h}$ & $4 \mathrm{~h}$ & \\
\hline Vehicle & - & $0.98 \pm 0.03$ & $1.02 \pm 0.03$ & $1.03 \pm 0.02$ & $1.00 \pm 0.02$ & 3.0 \\
CIT & 50 & $0.99 \pm 0.02$ & $0.97 \pm 0.02$ & $0.97 \pm 0.01$ & $0.98 \pm 0.01$ & $23.3^{\mathrm{d}}$ \\
CIT & 100 & $0.73 \pm 0.01^{\mathrm{c}}$ & $0.75 \pm 0.03^{\mathrm{c}}$ & $0.75 \pm 0.03^{\mathrm{c}}$ & $0.86 \pm 0.02^{\mathrm{b}}$ & $27.8^{\mathrm{d}}$ \\
CIT & 200 & $0.67 \pm 0.02^{\mathrm{c}}$ & $0.72 \pm 0.01^{\mathrm{c}}$ & $0.75 \pm 0.01^{\mathrm{c}}$ & $0.77 \pm 0.03^{\mathrm{c}}$ & $36.7^{\mathrm{e}}$ \\
INDO & 10 & $0.62 \pm 0.02^{\mathrm{c}}$ & $0.60 \pm 0.01^{\mathrm{c}}$ & $0.64 \pm 0.02^{\mathrm{c}}$ & $0.69 \pm 0.01^{\mathrm{c}}$ & \\
\hline
\end{tabular}

$\mathrm{n}=6$; ${ }^{a}$ Values represent mean $\pm \mathrm{SEM} ;{ }^{\mathrm{b}} p<0.01$ (one-way ANOVA and Tukey's test), significantly different from control; ${ }^{\mathrm{c}} p<0.001$ (one-way ANOVA and Tukey's test), significantly different from control; ${ }^{\mathrm{d}} p<0.05$ (Fisher's test), significantly different from control; ${ }^{\text {e }} p<0.01$ (Fisher`s test), significantly different from control.

Leme et al., 1973). In our experiments the edematous response was significantly suppressed in rats pre-treated with the CIT in the first phase of the edema, suggesting an inhibitory effect on the release of histamine and/or serotonin. In addition, CIT showed a significant inhibition of the edema in the second and third phase of edema, suggesting an inhibition of 5-lipoxygenase and/or cyclooxygenase, both enzymes involved in the formation of prostaglandins and leukotrienes. This edematous response was also significantly reduced in rats pre-treated with indomethacin, a compound known to be a cyclooxygenase inhibitor. It can be concluded that CIT is endowed with peripheral antinociceptive property as well as antiinflammatory activity. The precise mechanisms through which CIT exerts its action are currently under investigation, but possibly it could be related to the arachidonic acid cascade and/or modulation of pro-inflammatory molecules production. Therefore, this compound will be of potential benefit in the management of inflammatory pain conditions.

\section{Acknowledgment}

We thank Mr Osvaldo A. Santos for the technical support. This work was supported by grants from the Research Supporting Foundation of the State of Sergipe (Fundação de Apoio à Pesquisa e à Inovação Tecnológica do Estado de Sergipe) [grant number 019.203.00860/2009-6].

\section{References}

Amresh G, Reddy GD, Rao CV, Singh PN. 2007. Evaluation of anti-inflammatory activity of Cissampelos pareira root in rats. J Ethnopharmacol 110: 526-531.

Basbaum AI 1999. Spinal mechanisms of acute and persistent pain. Reg Anesth Pain Med 24: 59-67.

Batista PA, Werner MFP, Oliveira EC, Burgos L, Pereira P, Silva Brum LF, Story GM, Santos AR 2010. The antinociceptive effect of (-)-linalool in models of chronic inflammatory and neuropathic hypersensitivity in mice. $J$ Pain 11: 1222-1229
Bastos LF, Merlo LA, Rocha LT, Coelho MM 2007. Characterization of the antinociceptive and antiinflammatory activities of doxycycline and minocycline in different experimental models. Eur J Pharmacol 576: 171-179.

De Sousa DP, Gonçalves JCR, Quintans-Júnior LJ, Cruz JS, Araújo DAM, Almeida RN 2006. Study of anticonvulsant effect of citronellol, a monoterpene alcohol, in rodents. Neurosci Lett 401: 231-235.

De Sousa DP, Quintans LJ, Almeida RN 2007. Evaluation of the anticonvulsant activity of alfa-terpineol. Pharm Biol 45 : 69-70.

Deraedt R, Jouquey S, Delevallee F, Flauhaut M 1980. Release of prostaglandins $\mathrm{E}$ and $\mathrm{F}$ in an algogenic reaction and its inhibition. Eur J Pharmacol 61: 17-24.

Duarte IDG, Nakamura M, Ferreira SH 1988. Participation of the sympathetic system in acetic acid-induced writhing in mice. Braz J Med Biol Res 21: 341-343.

Gaertner M, Muller L, Roos JF, Cani G, Santos ARS, Niero R, Calixto JF, Yunes RA, Delle Monache F, CechinelFehho V 1999. Analgesic triterpenes from Sebastiania schottianan roots. Phytomedicine 6: 41-44.

Garcia-Leme J, Nakamura L, Leite MP, Rocha e Silva M 1973. Pharmacological analysis of the acute inflammation process induced in rat's pawby local injection of carrageenan and heating. Brit J Pharmacol 64: 91-98.

Guimarães AG, Oliveira GF, Melo MS, Cavalcanti SCH, Antoniolli AR, Bonjardim LR, Silva FA, Santos JPA, Rocha RF, Moreira JCF, Araújo AAS, Gelain DP, Quintans-Júnior LJ 2010. Bioassay-guided evaluation of antioxidant and antinociceptive activities of carvacrol. Basic Clin Pharmacol Toxicol 107: 949-957.

Gurgel do Vale T, Couto Furtado E, Santos Júnior JG, Viana GSB 2002. Central effects of citral, myrcene and limonene, constituents of essential oil chemotypes from Lippia alba (Mill.) N.E. Brown, Phytomedicine 9: 709-714.

Hunskaar S, Hole K 1987. The formalin test in mice: dissociation between inflammatory and non inflammatory pain. Pain 30: 103-114.

Hwang S, Lam M, Li C, Shen T 1996. Release of platelet activating factor and its involvement in the first phase of carrageenin rat foot edema. Eur J Pharmacol 120: 3341.

Katsukawa M, Nakata R, Takizawa Y, Hori K, Takahashi S, Inoue H 2010. Citral, a component of lemongrass oil, activates PPAR $\alpha$ and $\gamma$ and suppresses COX-2 expression. Biochim Biophys Acta 1801: 1214-1220. 
Koster R, Anderson M, Beer EJ 1959. Acetic acid for analgesic screening. Fed Proceed 18: 412-416.

Le Bars D, Gozariu M, Cadden SW 2001. Animal models of nociception. Pharmacol Rev 53: 597-652.

Lee HJ, Jeong HS, Kim DJ, Noh YH, Yuk DY, Hong JT 2008. Inhibitory effect of citral on NO production by suppression of iNOS expression and NF- $\mathrm{\kappa B}$ activation in RAW264.7 cells. Arch Pharm Res 31: 342-349.

Leite BLS, Bonfim RR, Antoniolli AR, Thomazzi SM, Araújo AAS, Blank AF, Estevam CS, Cambui EVF, Bonjardim LR, Albuquerque Júnior RLC, Quintans-Júnior LJ 2010. Assessment of antinociceptive, anti-inflammatory and antioxidant properties of Cymbopogon winterianus leaf essential oil. Pharm Biol 48: 1164-1169.

Lima-Accioly PM, Lavor-Porto PR, Cavalcante FSA, Magalhaes PJC, Lahlou S, Morais SM, Leal-Cardoso JH 2006. Essential oil of Croton nepetaefolius and its main constituent 1,8 cineole, block excitabiliry of rat sciatic nerve in vitro. Clin Exp Pharmacol 33: 1158-1163.

Loram LC, Fuller A, Fick LG, Cartmell T, Poole S, Mitchell D 2007. Cytokine profiles during carrageenan-induced inflammatory hyperalgesia in rat muscle and hind paw. $J$ Pain 8: 127-136.

Luster AD, Alon R, von Andrian UH 2005. Immune cell migration in inflammation: Present and future therapeutic targets. Nat Immunol 6: 1182-1190.

Ma F, Zhang L, Westlund KN 2009. Reactive oxygen species mediate TNFR1 increase after TRPV1 activation in mouse DRG neurons. Mol Pain 5: 1-11.

McCurdy CR, Scully SS 2005. Analgesic substances derived from natural products (natureceuticals). Life Sci 78: 476484.

Melo MS, Sena LCS, Barreto FJN, Bonjardim LR, Almeida JRGS, Lima JT, De Sousa DP, Quintans-Júnior LJ 2010. Antinociceptive effect of citronellal in mice. Pharm Biol 48: 411-416.

Mendell JR, Sahenk Z 2003. Painful sensory neuropathy. N Engl J Med 348: 1243-1255.

Menezes IAC, Moreira IJA, Paula JWA, Blank AF, Antoniolli AR, Quintans-Júnior LJ, Santos MRV 2010. Cardiovascular effects induced by Cymbopogon winterianus essential oil in rats: involvement of calcium channels and vagal pathway. J Pharm Pharmacol 62: 215-222.

Quintans-Júnior LJ, Souza TT, Leite BS, Lessa NMN, Bonjardim LR, Santos MRV, Alves PB, Blank AF, Antoniolli AR 2008a: Phythochemical screening and anticonvulsant activity of Cymbopogon winterianus Jowitt (Poaceae) leaf essential oil in rodents. Phytomedicine 15: 619-624.
Quintans-Júnior LJ, Almeida JRGS, Lima JT, Nunes XP, Siqueira JS, Oliveira LEG, Almeida RN, Athayde-Filho PF, Barbosa-Filho JM 2008b. Plants with anticonvulsant properties - a review. Rev Bras Farmacogn 18: 798-819.

Quintans-Júnior LJ, Melo MS, De Sousa DP, Araújo AAS, Onofre ACS, Gelain DP, Gonçalves JCR, Araújo DAM, Almeida JRGS, Bonjardim LR 2010. Antinociceptive activity of citronellal in formalin-, capsaicin- and glutamateinduced orofacial pain in rodents and its action on nerve excitability. J Orofac Pain 24: 305-312.

Salvemini D, Wang ZQ, Wyatt PS, Bourdon DM, Marino MH, Manning PT, Currie MG 1996. Nitric oxide: A key mediator in the early and late phase of carrageenaninduced rat paw inflammation. Br J Pharmacol 118: 829838.

Silva MR, Ximenes RM, Costa JGM, Leal KAM, Lopes AA, Viana GSB 2010. Comparative anticonvulsant activities of the essential oils (EOs) from Cymbopogon winterianus Jowitt and Cymbopogon citratus (DC) Stapf. in mice. Naunyn-Schmiedeberg's Arch Pharmacol 381: 415-426.

Stotz SC, Vriens J, Martyn D, Clardy J, Clapham DE 2008. Citral sensing by transient receptor potential channels in dorsal root ganglion neurons. PLOS ONE 3: 1-14.

Vinegar R, Truax JF, Selph JL, Johnston PR, Venable AL, McKenzie KK 1987. Pathway to carrageenan-induced inflammation in the hind limb of the rat. Fed Proceed 46: $118-126$

Waning J, Vriens J, Owsianik G, Stüwe L, Mally S, Fabian A, Frippiat C, Nilius B, Schwab A. 2007. A novel function of capsaicin-sensitive TRPV1 channels. Cell Calcium 42: $17-25$.

Winter CA, Riseley EA, Nuss GW. 1962. Carrageenan-induced edema in the hind paw of the rats as an assay for antiinflammatory drugs. Proc Soc Exp Biol Med 111: 544547.

Zimmermann M 1983. Ethical guidelines for investigations of experimental pain in conscious animals. Pain 16: 109110.

\section{*Correspondence}

Lucindo J. Quintans-Júnior

Departamento de Fisiologia, Universidade Federal de Sergipe

Campus Universitário "Prof. Aloísio de Campos", Av. Marechal Rondon, s/n, Jardim Rosa Elze, 49.000-100 São Cristóvão-SE, Brazil

lucindo@ufs.br, lucindo@pq.cnpq.br

Tel/Fax: +55 792105 6645; +55 7921056474 